\title{
REVIEW: ZWARTE HOLLANDERS
}

\section{Transforming Cultures eJournal, \\ Vol. 3 No 2, November 2008 \\ http://epress.lib.uts.edu.au/journals/TfC}

\section{Theo van Leeuwen ${ }^{1}$}

Review: Zwarte Hollanders - Afrikaanse soldaten in Nederlands-Indië, Ineke van Kessel. (Black Dutchmen - African soldiers in Dutch Indonesia), Amsterdam, KIT Publishers, 2005. ISBN 90-6832-498-5, pp. 304.

Between 1831 and 1872 Holland recruited approximately 3100 soldiers in West Africa, mostly from what is today Ghana and Burkina Faso. These soldiers fought in Sumatra, Borneo, Sulawesi, Bali, Timor and Aceh with the Dutch colonial army, the KNIL ('Royal Dutch Indian Army - the Dutch colonizers referred to Indonesia as 'Nederlands Indië', 'Dutch India').

Based on extensive and detailed historical research and written as a lively narrative, the book developed from interviews with descendants from these soldiers who now live in the Netherlands, and is punctuated with intimate and sympathetic portraits of individual members and families from this community. It tells of the protracted early $19^{\text {th }}$ century debates about building the strength of the colonial army ('for service in India, Negroes seem the very thing; they are sure not to fraternize with the natives. We shall recognize the wisdom of the Romans, who garrisoned each province with troops from a distance", quoted on p. 15); of the recruitment process which only gained momentum when the Dutch Government began to buy slaves, because "No African contemplates leaving the place of his birth. Outside the hut in which rest the bones of his forefathers, nothing is sacred to the negro" (quoted on p. 47); of the 'small but vibrant communities' in which the African soldiers lived with their 'sarinahs', their Indonesian partners, and their children, in relative isolation from their neighbours; of the wars they, and their sons and grandsons, fought, and the medals they earned ("Give him what is due to him, and the African is an excellent soldier...tireless and with the courage of a lion", quoted on $\mathrm{p}$.

\footnotetext{
1 Professor Theo van Leeuwen is Dean for the Faculty of Arts and Social Sciences, University of Technology, Sydney. He has written many books and articles on discourse analysis, visual communication and multimodality. His research interests include social semiotics, critical discourse analysis and multimodality.
} 
156); and of the eventual repatriation of most of them to the Netherlands, after Indonesian independence.

Throughout the book, the African soldiers are described as true Hollanders who like their 'borreltje' (Dutch gin), go to Church and adore the Queen. When a GovernorGeneral inspects the troops, "a black sergeant raises his glass, followed by the other Africans at his table and exclaims:

Face Black

Heart White

Long live the King"

And when, today, a descendant of these African soldiers, was interviewed while on a holiday in Ghana, she said "I am just an ordinary cheese girl with a colour, but one who is curious to know where she came from, and proud of it" (p.12).

The life of the soldiers in Indonesia is drawn with the nostalgia for the tempoe doeloe which any Dutch person of my generation is only too familiar with, with detailed accounts of happy childhoods in those 'small, vibrant communities' with their comfortable, 'gezellig' ('cosy') Dutch family life, and family snapshots throughout the book ("Bert Klink throws his first snowball").

From those 'small but vibrant' communities, however, the men went out to fight, for instance, the Aceh war, one of the longest and bloodiest in Dutch colonial history. The book recounts the bravery of the African soldiers ("An African soldier, J. Vijl, who had been shot in the head, bandaged himself and immediately rejoined the attackers", p.152), and lists the medals they received and the names of those who perished, but the other side of the story remains largely undeveloped (no family snapshots of the Indonesians who were massacred), and emerges only occasionally, as when Ghanaians, meeting the descendants of the 'Black Dutchmen', are astounded to hear that they fought against Sukarno.

Although the Dutch were notorious slave traders, decades behind the UK in abolishing slavery, the recruitment of slaves and the transport to Indonesia is described as benign, the Dutch responses to British objections as entirely reasonable. The slaves were bought from the King of Ashanti and "to see their recruitment as slave trade is untenable, as 
without doubt their fate is improved and they are wrested away from a certain death" (quoted on p.117). All were able to buy their freedom from their future wages. "They were delighted to receive a shirt, trousers, vest and cap, and to be given pleasant rooms to stay in" (p.121). The journeys to Indonesia were uneventful, although an 1837 report from a German ship's doctor throws another light on this "Our negroes had been slaves from a young age and only some could remember their country of birth or their parents, For this reason they were indifferent when they left Africa. No-one tried to escape, even though they had plenty of opportunity to do so" (quoted on p. 89).

In many ways Black Dutchmen is a fascinating book. Its detailed account of $19^{\text {th }}$ century racist discourses is memorable, as is the chapter about a late $19^{\text {th }}$ century Dutch boys' adventure book, The Black Prince, in which the protagonist is an African soldier who is also an Ashanti prince. Yet, despite its carefully balanced tone of reasonability, I cannot help reading this book as another self-congratulatory expression of Dutch tolerance which somehow lacks the courage to take a close look at the ruthlessness with which the Dutch have conducted their trade and conquered their colonial empire. For such a book to appear in a time where nostalgia for an already lost Dutchness becomes a key weapon for the growing anti-immigration lobby, is worrying. 